\title{
Last interglacial (MIS 5e) surface water conditions at the Vøring Plateau (Norwegian Sea), based on dinoflagellate cysts
}

\author{
Nicolas Van Nieuwenhove ${ }^{1}$ \& Henning A. Bauch ${ }^{1,2}$ \\ 1 Leibniz Institute of Marine Sciences, University of Kiel, Wischhofstr. 1-3, DE-24148 Kiel, Germany \\ 2 Mainz Academy of Sciences, Humanities and Literature, Geschwister-Scholl-Str. 2, DE-55131 Mainz, Germany
}

\section{Keywords}

Dinoflagellate cysts; Holocene; last interglacial; marine isotope stage 5e; transfer functions.

\section{Correspondence}

Nicolas Van Nieuwenhove, Leibniz Institute of Marine Sciences, University of Kiel, Wischhofstr. 1-3, DE-24148 Kiel, Germany. E-mail: nvannieuwenhove@ifm-geomar.de

doi:10.1111/j.1751-8369.2008.00062.x

\begin{abstract}
Sediments from the last interglacial, marine isotope stage 5e (MIS 5e), have been studied for their dinoflagellate cyst content in a core retrieved from the Vøring Plateau, Norwegian Sea. Qualitative and quantitative analyses of the data, and comparison with the surface sample and published Holocene data from the core, reveal distinct differences in hydrological surface conditions between the late Holocene and MIS 5e. A higher number of co-dominant, subordinate species in the last interglacial samples suggests there was a more pronounced seasonality of the surface water at this time. This is supported by the significant presence of Bitectatodinium tepikiense, a species that was virtually absent from the area for most of the Holocene. The seasonality signal is further substantiated by transfer-function reconstructions, which also indicates a stronger stratification of the upper water column during MIS 5e. Moreover, the assemblage data clearly show that optimal, fully marine interglacial conditions prevailed only late in MIS 5e (between ca. 117.5 and $116.5 \mathrm{Kya}$ ), which is in contrast with the climatic optimum early in the Holocene. Stable oxygen isotope values from planktic foraminifera for this MIS 5e optimum are comparable with the average Holocene values, but are generally ca. $0.3 \%$ higher than those of the earlier part of the last interglacial (sensu stricto). These higher $\delta^{18} \mathrm{O}$ values are likely to be the result of the enhanced and prolonged influence of Saalian deglacial meltwater, thus corroborating the existence of a quite differently structured sea surface, as suggested by the dinocyst data.
\end{abstract}

In search for possible analogues for the Holocene, and future climate development, many studies have focussed on the last interglacial period, known as marine isotope (sub)stage 5e (MIS 5e). Not only is MIS 5e the most recent and thus easily recoverable interglacial (sensu stricto) interval, it was also similar to the Holocene in terms of evolution of orbital configuration, with the highest summer irradiance ocurring during the early phases of the interglacial (Berger 1978). Accordingly, terrestrial and marine-based proxy records indicate that there was an early last interglacial optimum for western Europe and the temperate North Atlantic domain (e.g., Cheddadi et al. 1998; Sánchez-Goñi et al. 1999; Rioual et al. 2001; Rousseau et al. 2006; Bauch \& Kandiano 2007).

Stratigraphical exercises have shown that MIS 5e roughly correlates with the terrestrial Eemian stage (e.g., Shackleton 1969; Mangerud et al. 1979; Mangerud 1989). The absolute timing of the onset of the last inter- glacial is a topic of debate, because of the scarcity of radiometric dating, difficulties in correlating pollen records across Europe and tying them to the marine isotopic stratigraphy, and uncertainties concerning the synchronicity of interglacial climate development between land and the marine realm. Nonetheless, the onset of the last interglacial period is generally believed to be around 131-125 Kya for temperate European latitudes (e.g., Shackleton et al. 2003; Beets et al. 2006; Brauer et al. 2007). However, it has also been shown that a substantial part of the high northern marine sediment sections commonly assigned to MIS 5e, on the basis of oxygen isotope chronology, belongs stratigraphically to the deglacial phase of the preceding glaciation MIS 6 or to the Saalian (Bauch et al. 1996). The extent of the Saalian ice sheets over northern Eurasia was considerably larger than during the Last Glacial Maximum (e.g., Svendsen et al. 2004), and it has been suggested that the meltwater 
released from these ice sheets into the northern polar oceans during deglaciation (Termination II) had a longlasting effect on the structure of the water column and the development of the subsequent interglacial thermohaline circulation (Bauch \& Kandiano 2007). Our study area is located at the outer edge of the North Atlantic polar region along the pathway of inflowing warm Atlantic surface water, and is thus well situated to trace the possible influences of meltwater interacting with North Atlantic water masses.

Dinoflagellate cysts (dinocysts), the organic-walled remains of certain algae, are well suited for reconstructing palaeoenvironmental changes in the upper water layer, especially in polar regions where calcareous or siliceous biogenic proxies might suffer from low diversity or bad preservation. The dinocyst assemblage distribution in surface sediments is clearly related to surface water parameters such as salinity, temperature and sea-ice cover (e.g., Rochon et al. 1999; de Vernal et al. 2001; Marret \& Zonneveld 2003; Marret et al. 2004). Hence, dinocysts have been used for a number of detailed last interglacial palaeoenvironmental reconstructions in regions surrounding our study area: the Baltic/North Sea (Eriksson et al. 1999; Van Leeuwen et al. 2000; Head et al. 2005; Head 2007); off western Europe (SánchezGoñi et al. 1999; Eynaud 1999; Eynaud et al. 2000; Sánchez-Goñi et al. 2000; Penaud et al. 2008); Norwegian fjords (Dale 1996); the White Sea region (Grøsfjeld et al. 2006); the Arctic Ocean margin (Matthiessen \& Knies 2001; Matthiessen et al. 2001); and south of Iceland (Eynaud et al. 2004). However, the hydrographical context, and hence the deglacial/postglacial evolution, of all but the latter two of these sites is very different from the full-oceanic setting, along the pathway of the Norwegian Atlantic Current, of our site on the Vøring Plateau. In addition, previous low-resolution records (Matthiessen \& Knies 2001; Matthiessen et al. 2001) only provided a stratigraphical allocation of the MIS 5e interval, rather than a qualitative palaeoceanographic elaboration. Thus, despite the importance of the Nordic seas in terms of climate dynamics, the palaeoceanographical potential of dinocyst assemblages has rarely been applied to the last interglacial sections from this region.

The aim of our present study was to give some insights into how the particular deglacial history of MIS 6 has influenced the structure and evolution of the upper water column at the Vøring Plateau during MIS 5e. This will be achieved by qualitative and statistical analysis of last interglacial dinocyst assemblage data, including a direct comparison with the surface sample and published Holocene data from the same core (Baumann \& Matthiessen 1992), as a modern and interglacial reference, respectively.

\section{Material and methods}

\section{Core location and hydrography}

Core M23071 was retrieved from the Vøring Plateau in the Norwegian Sea $\left(67^{\circ} 05.1^{\prime} \mathrm{N}, 2^{\circ} 54.4^{\prime} \mathrm{E}\right)$ at a water depth of $1306 \mathrm{~m}$ (Gerlach et al. 1986) (Fig. 1). The site is directly influenced by the relatively warm and highsalinity surface waters of the North Atlantic Drift (NAD), which cross the Vøring Plateau as the Norwegian Current (NC), and move further north into the Eurasian Basin of the Arctic Ocean through Fram Strait and across the Barents Sea. Surface waters at site M23071 have at present winter and summer temperatures of 6.3 and $10.6^{\circ} \mathrm{C}$, and salinities of 35.2 and 35.0 , respectively (Boyer et al. 2006). The NC can be influenced by the Norwegian Coastal Current (NCC) to the east, which carries fresher water masses, originating from the Baltic Sea, northwards along the coast of Norway to the North Cape (Hopkins 1991) (Fig. 1). To the west, the warm and saline waters of the NC mix with the cold and low-salinity surface waters that branch off from the southwards flowing East Greenland Current (EGC).

\section{Core lithostratigraphy and age model}

The interglacial intervals of core M23071 consist mainly of brown-grey clays, silts and sands. The sand fraction is largely composed of foraminiferal shells, which is a typical feature of late Pleistocene interglacial sediments from the area (Gerlach et al. 1986). High contents of ice-rafted debris (IRD) characterize the glacial, deglacial and stadial intervals. The stratigraphic subdivision of this core is based on radiocarbon dates, the identification of discrete tephras with known ages for the younger parts of the core (Vogelsang 1990; Voelker 1999) and stable oxygen isotopes derived from the planktic foraminifer Neogloboquadrina pachyderma left-coiling (s). The $\delta^{18} \mathrm{O}$ curve shown in Fig. 2 is composed of densely sampled (1-cm interval) data for both the Holocene and for core depths greater than $577 \mathrm{~cm}$ (Voelker 1999; Van Nieuwenhove et al. 2008), and low-resolution data for the rest of the core (Vogelsang 1990). The isotope curve is typical for the Nordic seas, showing a stepwise decrease in $\delta^{18} \mathrm{O}$ from MIS 6 to MIS 5e during Termination II (e.g., Fronval \& Jansen 1997; Bauch et al. 2000), and having the lowest isotope values seen in the Holocene and last interglacial (e.g., Vogelsang 1990; Bauch et al. 1999). The Pullenia bulloides horizon and more highly resolved oxygen isotope data from this specific interval (Haake et al. 1992: fig. 8; Voelker 1999) clearly identify the stratigraphic position of substage $5 \mathrm{a}$ in core M23071-3 (Fig. 2). Oxygen isotope values, the level of IRD (counted in the $>150-\mu \mathrm{m}$ size fraction, and expressed as grains per gram 
Fig. 1 Location of core site M23071 and modern surface circulation currents in the Norwegian Sea. Grey arrows represent warm surface currents; black arrows represent cold surface currents. Abbreviations: EGC, East Greenland Current; NAD, North Atlantic Drift; NC, Norwegian Current; NCC, Norwegian Coastal Current.

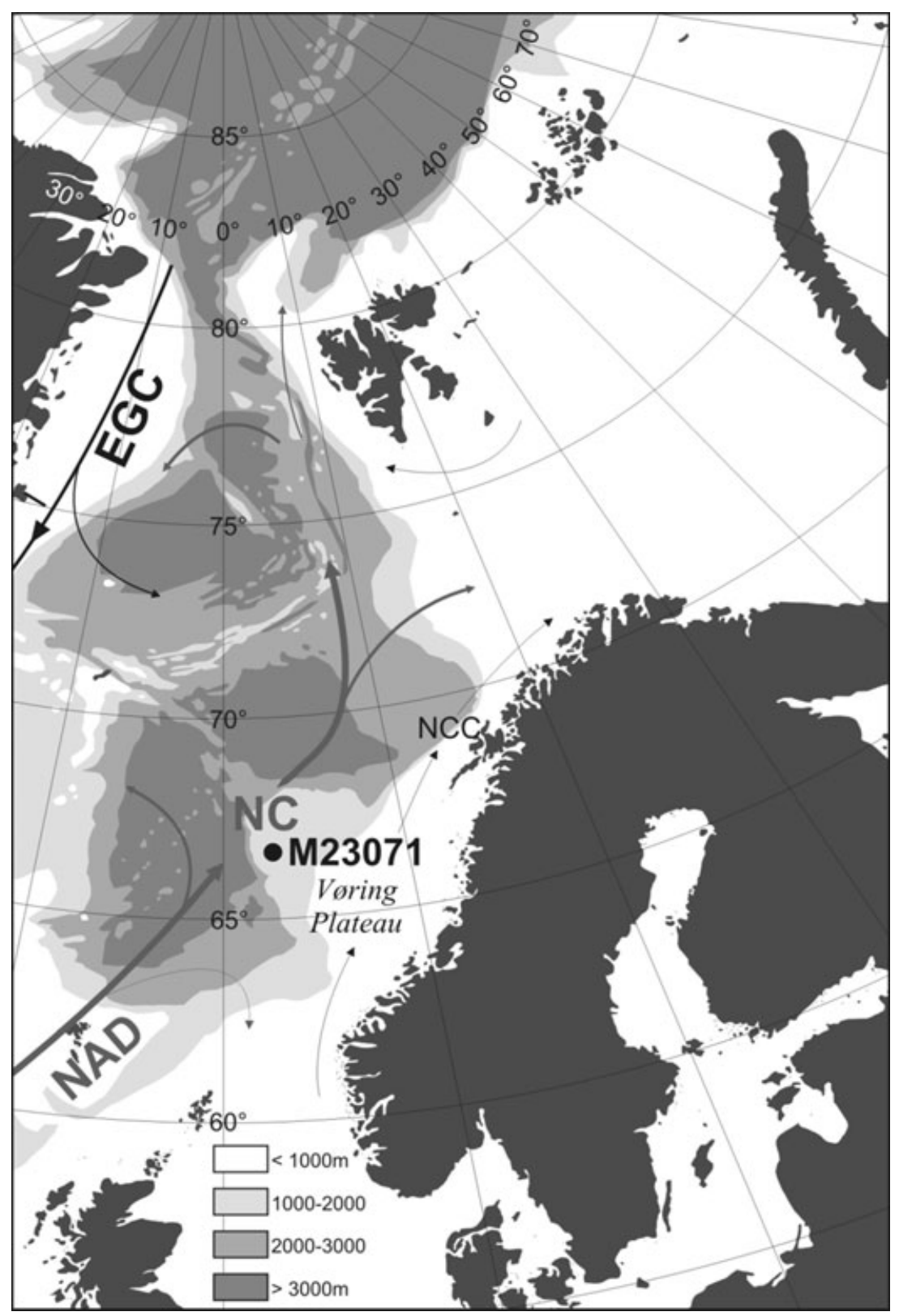

of dried sediment), and foraminiferal and dinocyst assemblages confirm the position of MIS 5e below. The age model for MIS 5e was developed by identifying major SPECMAP events in the $\delta^{18} \mathrm{O}$ record (Martinson et al. 1987; see Fig. 2, Table 1) and correlating these marker points with a $\delta^{18} \mathrm{O}$ record of a core with relatively constant sedimentation rates across MIS 5e (see Bauch $\delta$ Erlenkeuser 2008 [this issue]). Our derived age model agrees well with recent findings for the last interglacial sea level maximum (Rohling et al. 2008), i.e., the interval with the lowest oxygen isotope values (Fig. 2).

\section{Dinocyst analysis}

Samples of the last interglacial section of core M23071 were taken as consecutive 1 -cm-thick slices and freeze dried. From these samples, subsamples of ca. $5 \mathrm{~g}$ dryweight sediment were taken for dinoflagellate cyst analyses, before the remainder of each sample was sieved and studied for foraminiferal and IRD content in the fraction $>150 \mu \mathrm{m}$ (Van Nieuwenhove et al. 2008). Standard palynological preparation methods were applied on the subsamples selected for dinoflagellate analysis. This 


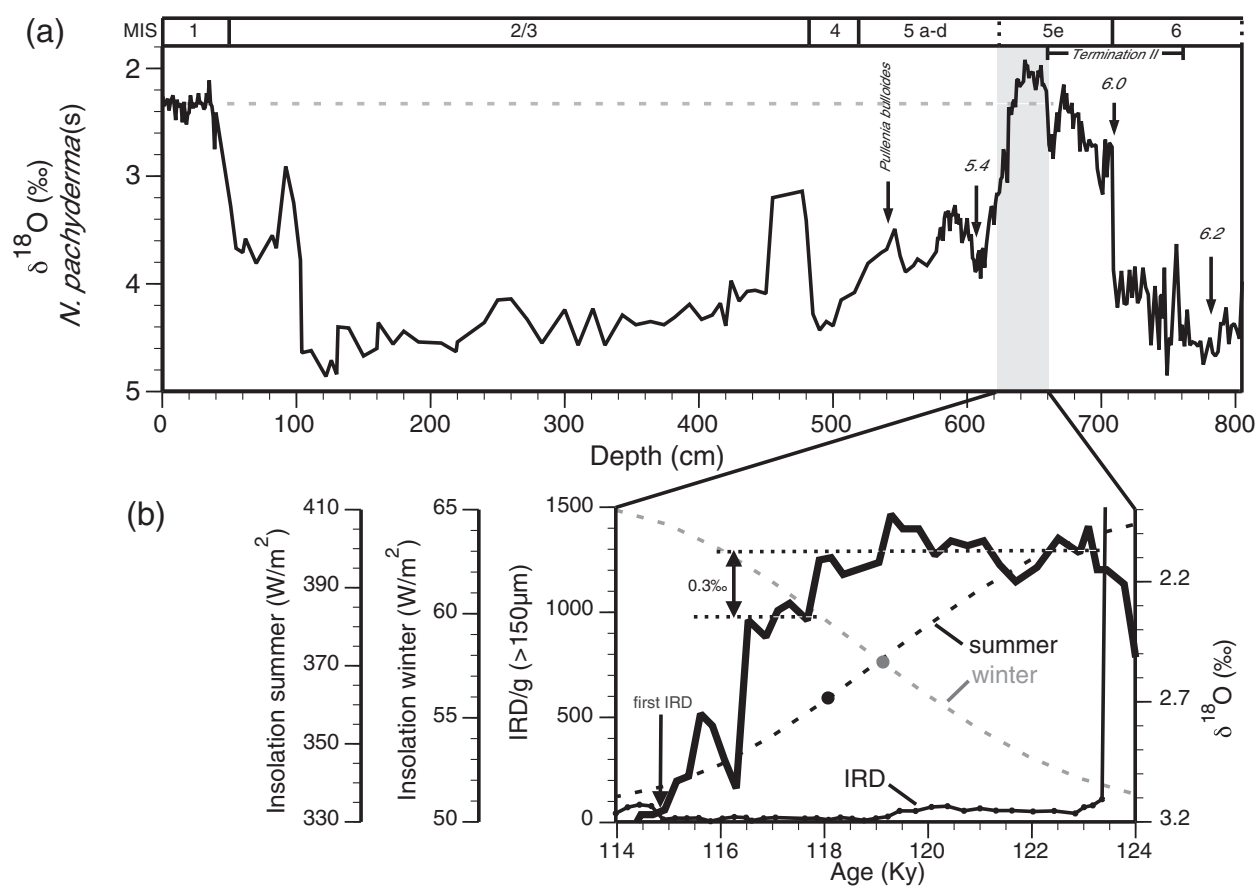

Fig. 2 (a) Planktic foraminifer stable oxygen isotope stratigraphy of core M23071, plotted against depth (Vogelsang 1990; Voelker 1999; Van Nieuwenhove et al. 2008). The dashed grey line indicates the average Holocene $\delta^{18} \mathrm{O}$ value, for comparison with MIS 5e. (b) Stable oxygen isotopes, ice-rafted debris (IRD) content, and summer and winter insolation at 65으 [computed with ANALYSERIES 2.0 (Paillard et al. 1996) using the Laskar et al. (2004) data] for the last interglacial interval studied, plotted against age. The dots on the insolation curves represent the present-day values. Note the ca. $0.3 \%$ difference (arrow in between the dotted grey lines) between the average value for the largest, first part of MIS 5e, and the short plateau from the latest phase, for which fully marine interglacial conditions are interpreted (see Van Nieuwenhove et al. 2008). The latter value corresponds well with the average Holocene value.

procedure involves using cold $\mathrm{HCl}(8-10 \%)$ and $\mathrm{HF}$ $(40 \%)$ to remove carbonates and silicates, respectively, and then washing through a 150- and 6- $\mu \mathrm{m}$ polymer mesh. The organic residue was mounted on microscope slides using glycerine jelly. No sonication, oxidation or staining was carried out. A minimum of 500 cysts was counted for every sample, using a Zeiss Axiophot light microscope. Following the marker grain method (e.g., Stockmarr 1971), one Lycopodium clavatum tablet (batch no. 483216 , equivalent to 18583 spores per tablet) was added to each sample for calculating the absolute concentrations of dinocysts per gram dry sediment. Unidentified taxa were left out of the total sum of specimens for calculating percentage abundances.

Specimens were differentiated at species level wherever possible. However, some taxa were grouped during counting when unfavourable orientation or preservation did not allow determination on a species level, or afterwards, in order to assure conformity with previously published records, also discussed here. Any grouping generally followed the scheme of Rochon et al. (1999); more details about the groupings of our dataset can be found in Van Nieuwenhove et al. (2008). The existing slides of the core-top sample of site M23071 (Baumann \& Matthiessen 1992) were recounted to enable optimal comparison with the last interglacial samples.

Quantitative reconstructions for sea surface temperature (SST) and salinity (SSS) were performed for the last interglacial and core-top sample dinocyst datasets using the best-analogue technique, as originally developed by Overpeck et al. (1985) and Guiot (1990) for pollen assemblages, and adapted for dinocyst assemblages by de Vernal et al. (2001) and de Vernal et al. (2005). This technique involves a logarithmic transformation of the relative abundances (in per mille) of all taxa (29 in total after grouping) prior to analysis, in order to increase the weight of rare species, which presumably have narrower ecological requirements. The five closest analogues are then searched for amongst the modern spectra on the basis of even weighting of the taxa through use of the " $R$ " software package (R Development Core Team 2007). The modern database consists of a total of 1171 surface samples from the Arctic, North Atlantic and North Pacific basins (Radi \& de Vernal 2008). The most probable estimate for a specific hydrological parameter is calculated as the average of the five analogues inversely weighted by 
their respective distances. A confidence interval was calculated from the variances in the set of analogues around the most probable estimate. The degree of accuracy of the approach is assessed by comparing measured modern values (Boyer et al. 2006) with the estimated values reconstructed from the core-top sample. This comparison reveals an accuracy of \pm 1.6 and $\pm 1.1^{\circ} \mathrm{C}$ for winter and summer SST, respectively, and \pm 0.1 for both winter and summer SSS. Such relatively high precision is expected considering the surface sample of M23071 is part of the database used for the reconstructions.

\section{Results}

The lowermost part of our studied interval has high IRD content, and therefore represents the latest phase of Termination II. Hence, fully interglacial conditions sensu stricto (i.e., characterized by a more pelagic sedimentation with little or no IRD) existed at the Vøring Plateau from about 123 to 115.5 Kya (Fig. 2).

The total cyst abundances and the relative abundances of the most frequent species are shown in Fig. 3. Except for the earliest MIS 5e and a few data points afterwards, the number of cysts per gram dry sediment varies between 20000 and 40 000, which is the same order of magnitude as seen in the late-Holocene samples from core M23071 (Baumann \& Matthiessen 1992). Operculodinium centrocarpum is the dominant species in all of our samples. It makes up between 50 and $65 \%$ of the assemblages from the last interglacial samples, and around $80 \%$ in the core-top sample. The most abundant subordinate species in the last interglacial interval are Nematosphaeropsis labyrinthus and Bitectatodinium tepikiense, but many other species also regularly make up several percent of the assemblages (see Van Nieuwenhove et al. 2008 for a detailed description of the last interglacial assemblages). This is in strong contrast with the core-top sample, where only O. centrocarpum, $N$. labyrinthus and cysts of Pentapharsodinium dalei have relative abundances above $1 \%$. The diagrams in Fig. 4 illustrate this difference in assemblage composition with respect to the secondary and rare species. The dinocyst assemblage in the core-top sample can be regarded as representative for the modern and average late-Holocene sea surface conditions, as the assemblage composition remained constant in core M23071 for the last ca. $7 \mathrm{Ky}$ (Baumann \& Matthiessen 1992).

The transfer-function exercise was able to find five analogues for all samples. The distances between the MIS 5e assemblages and the modern analogues are rather large, especially compared with the core-top sample, but they still remain below the threshold value (1.26) beyond which an analogue is rejected (Table 1). The

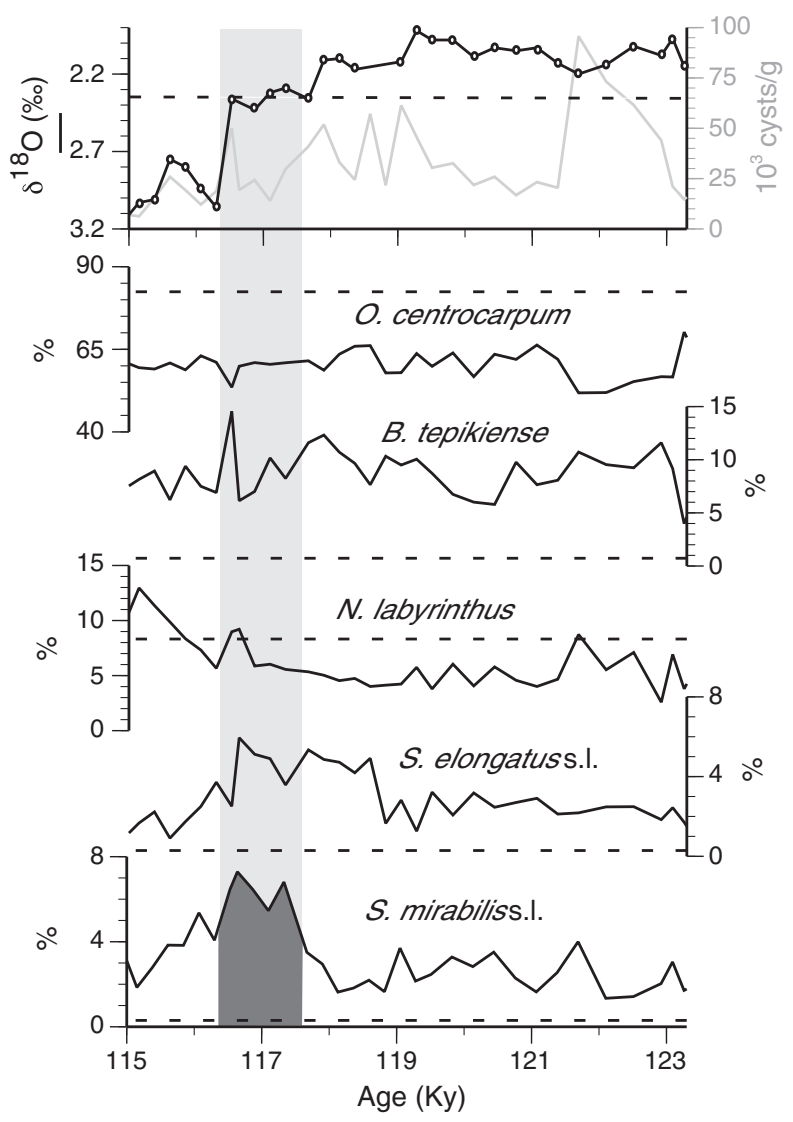

Fig. 3 Cyst concentrations per gram dry sediment for the last interglacial samples, and relative abundances of the most frequent dinocyst species in the last interglacial samples and the core-top sample (dashed grey horizontal lines). Oxygen isotopes for MIS $5 \mathrm{e}$ and the average Holocene $\delta^{18} \mathrm{O}$ value (dashed lines) are plotted for reference. The grey bar indicates the time interval with optimal, marine interglacial conditions, as suggested by the peak abundances of Spiniferites mirabilis s.l. and subpolar foraminifera (not shown here; see Van Nieuwenhove et al. 2008).

results from the transfer-function analyses show that significant fluctuations occurred during MIS 5e in the reconstructed parameters (Fig. 5). Winter and summer SST reconstructions vary from 1.6 to $9.2^{\circ} \mathrm{C}$ and from 11.2 to $21.4^{\circ} \mathrm{C}$, respectively. The summer SSTs of $20^{\circ} \mathrm{C}$ and more, and the short-term changes of over $5^{\circ} \mathrm{C}$ during the earliest phases of MIS 5e, could be a real signal, but should be regarded cautiously. The distances to their closest analogues are among the highest of all the reconstructions (Table 1), and their analogue sites are situated most distally, in the western North Atlantic off the North American coast. After 122 Kya, a clear increasing trend is discernable in the winter SST, reaching temperatures higher than the present-day (reconstructed) value by ca. 118.5 Kya, and exceeding the modern estimate between ca. 117.5 and $116.5 \mathrm{Kya}$ (Fig. 5). A similar trend is not found in the summer SSTs, which are otherwise 
(a)
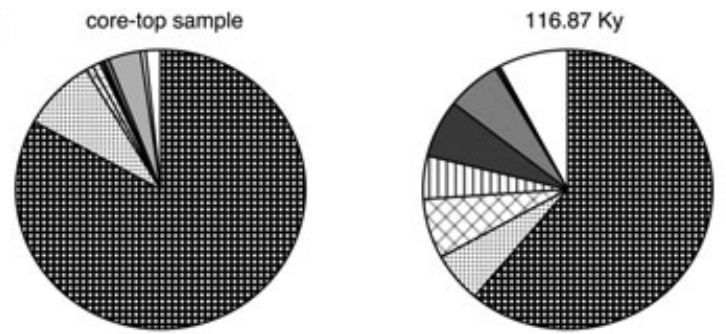

(b)

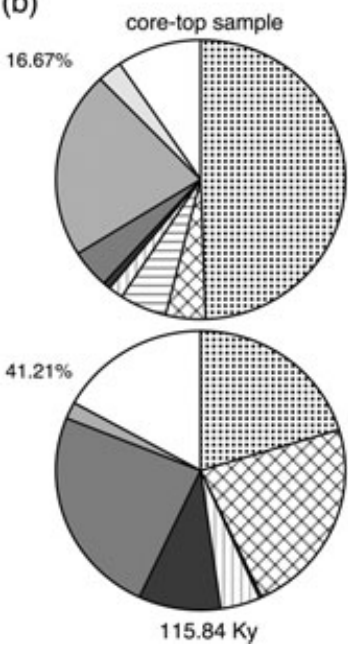

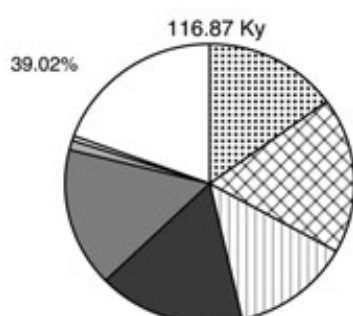

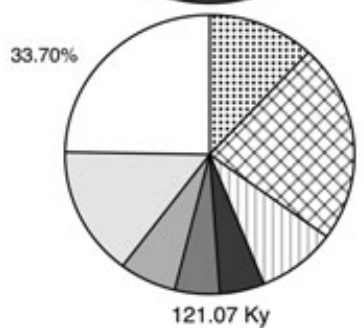

带册

0. controcarpum

N. labyrinthus

B. tepikiense

(1)

S. elongatus

S. mirabilis

S. ramosus

P. dalei

Brigantedinium spp.

Other
Fig. 4 (a) Assemblage composition in the core-top sample and in a sample from the last interglacial optimum, illustrating the difference in assemblage composition between both phases. (b) Comparison of the composition of the subordinate assemblage (i.e., excluding Operculodinium centrocarpum) in the core-top sample with samples from three different phases of the last interglacial period. The percentage number to the upper left of each diagram gives the percentage of the total assemblage that is represented by the diagram, i.e., 100 minus the relative abundance percentage of $O$. centrocarpum in the respective sample. consistently higher than the reconstructed present-day value. Estimated values for SSS range from 32.5 to 35.0 and from 31.6 to 34.7 for winter and summer, respectively. Analogous with the winter SST, salinity gradually increases and reaches the highest values between ca. 118 and 116.5 Kya, immediately after a notable shift in salinity of ca. 1. Winter SSS values are close to the reconstructed present-day value during this interval (118-116.5 Kya), but never exceed the value of the core-top sample reconstruction.

\section{Discussion}

Dinocyst assemblages dominated by $O$. centrocarpum are a common feature of both Holocene and last interglacial sediments from areas influenced by inflowing Atlantic water (e.g., Baumann \& Matthiessen 1992; Eynaud et al. 2004). Because it is believed that this species thrives in waters of the NAD (Harland 1983; Matthiessen 1995; Rochon et al. 1999), it has been used as a Quaternary tracer for NAD waters as they penetrated into high northern latitudes (Matthiessen \& Knies 2001; Matthiessen et al. 2001; Grøsfjeld et al. 2006). Indeed, species assemblages at the Vøring Plateau and in western Norway became dominated by 0 . centrocarpum after ca. 7 Kya, and this has been interpreted as reflecting the onset of the modern mode of surface circulation (Baumann $\delta$ Matthiessen 1992; Grøsfjeld et al. 1999). However, the qualitative existence of an "interglacial type" of surface circulation with inflowing Atlantic water is the only conclusion that can be derived from the dominance of $O$. centrocarpum, as this cosmopolitan species occurs over a wide range of salinity, temperature and sea-ice cover conditions (see Marret \& Zonneveld 2003).

It has been shown that secondary and rare species may offer greater insight, as they often have more restricted ecological preferences (Dale 1976). In this respect, it is interesting to see the considerable difference in assemblage compositions between the core-top sample and the last interglacial samples. A preservational bias overprinting on the assemblages is unlikely, because most of the dominant species are more or less equally resistant to oxidation (Zonneveld et al. 2001). The difference between the core-top and last interglacial samples becomes obvious when comparing the assemblage composition of the core-top sample with time slices from MIS $5 \mathrm{e}$, taking into account all species other than $O$. centrocarpum (Fig. 4). Although most species frequently observed in the MIS 5e section also occur in the surface sample, the MIS 5e assemblages may be regarded as "more diverse". 
Table 1 Sample depths, correlated interpolated ages, and minimum and maximum distances to the analogues.

\begin{tabular}{|c|c|c|c|}
\hline \multirow[b]{2}{*}{ Depth (cm) } & \multirow[b]{2}{*}{ Age (Ky) } & Min. dist. & Max. dist. \\
\hline & & \multicolumn{2}{|c|}{ (threshold 1.26) } \\
\hline core-top sample & & 0.13 & 0.18 \\
\hline 625 & 115.15 & 0.46 & 0.62 \\
\hline 626 & 115.38 & 0.44 & 0.59 \\
\hline 627 & 115.61 & 0.41 & 0.55 \\
\hline 628 & 115.84 & 0.46 & 0.59 \\
\hline 629 & 116.07 & 0.59 & 0.70 \\
\hline 630 & 116.30 & 0.62 & 0.71 \\
\hline 631 & 116.53 & 0.78 & 0.82 \\
\hline 632 & 116.64 & 0.67 & 0.75 \\
\hline 633 & 116.87 & 0.59 & 0.68 \\
\hline 634 & 117.10 & 0.70 & 0.76 \\
\hline 635 & 117.33 & 0.69 & 0.88 \\
\hline 636 & 117.67 & 0.54 & 0.65 \\
\hline 637 & 117.90 & 0.49 & 0.61 \\
\hline 638 & 118.13 & 0.68 & 0.78 \\
\hline 639 & 118.36 & 0.52 & 0.63 \\
\hline 640 & 118.59 & 0.66 & 0.74 \\
\hline 641 & 118.82 & 0.57 & 0.59 \\
\hline 642 & 119.05 & 0.63 & 0.74 \\
\hline 643 & 119.28 & 0.53 & 0.62 \\
\hline 644 & 119.51 & 0.57 & 0.61 \\
\hline 645 & 119.82 & 0.54 & 0.58 \\
\hline 646 & 120.13 & 0.55 & 0.61 \\
\hline 647 & 120.44 & 0.64 & 0.72 \\
\hline 648 & 120.76 & 0.65 & 0.74 \\
\hline 649 & 121.07 & 0.61 & 0.68 \\
\hline 650 & 121.38 & 0.52 & 0.63 \\
\hline 651 & 121.69 & 0.71 & 0.82 \\
\hline 652 & 122.10 & 0.61 & 0.70 \\
\hline 653 & 122.51 & 0.61 & 0.72 \\
\hline 654 & 122.92 & 0.72 & 0.75 \\
\hline 655 & 123.09 & 0.62 & 0.73 \\
\hline 656 & 123.26 & 0.65 & 0.79 \\
\hline
\end{tabular}

This is because greater numbers of co-dominant subordinate species contribute to the total assemblage composition in the MIS 5e samples, and the share made up by rare species is at least double as high as compared with the core-top sample (Fig. 4). For example, half of the core-top sample subordinate assemblage is comprised of $N$. labyrinthus, yet this species represents only $8 \%$ of the total core-top sample assemblage. The cosmopolitan species $N$. labyrinthus tolerates a wide range of temperature, but is generally associated with the subpolar to temperate high-salinity domains in the northern North Atlantic (Rochon et al. 1999). The fact that O. centrocarpum and N. labyrinthus constitute about $90 \%$ of the assemblage in the core-top sample is entirely consistent with the full marine conditions that prevail in the Norwegian Sea at present.

Identifying what caused the marked differences between the core-top and last interglacial assemblages is somewhat hindered by the fact that only little is known about the ecological preferences, timing of cyst formation and the growth conditions of most of the cyst-forming dinoflagellate species (see Matthiessen et al. 2005). A possible explanation for the assemblage differences may lie in the existence of a more pronounced surface water seasonality during MIS $5 \mathrm{e}$, creating thriving conditions for one or several species at differing times of the year. Evidence for stronger seasonality comes from B. tepikiense, a cold/temperate species that at present is abundant in embayments that are characterized by large seasonal temperature amplitudes (Rochon et al. 1999). This species is virtually absent in samples from the last $7 \mathrm{Ky}$ (Baumann \& Matthiessen 1992), but consistently constitutes around $9 \%$ of the last interglacial assemblages at site M23071 (Fig. 3). The general differences between the core-top and MIS 5e assemblages, especially clear in the relative abundances of B. tepikiense, point toward dissimilar sea-surface conditions during MIS 5e at the Vøring Plateau compared with conditions today. Such a finding has already been suggested for the Arctic margin based on similar observations in dinocyst assemblages (Matthiessen \& Knies 2001; Matthiessen et al. 2001), as well as for the North Atlantic, using planktic foraminiferal assemblages (Bauch \& Kandiano 2007).

Further support for a pronounced seasonality comes from the results of the transfer functions. These results show considerable differences between summer and winter surface water temperature and salinity, especially during the first ca. $5 \mathrm{Ky}$ of MIS 5e (Fig. 5). Based on the reconstructed lower salinities, a more stratified upper water column is implied to have been present during MIS 5e. A fresher, and hence more stratified, surface layer would store heat more easily during summer, giving rise to warmer, compared with the present, summer SSTs, but could also facilitate the formation of winter sea ice. Although an enhanced NCC could have contributed in generating the lower salinities, meltwater is the most likely freshwater source, as the marked salinity increase occurs after the IRD input had dropped to near-zero levels (Figs. 2, 5). This scenario of prolonged meltwater influence during MIS 5e is further supported by B. tepikiense: high abundances of this species, comparable with the ones from the last interglacial period at the Vøring Plateau, were found in Late Allerød sediments from the Norwegian Channel and the west Norwegian Voldafjorden (Rochon et al. 1998; Grøsfjeld et al. 1999). The latter two studies related these high abundances to strong seasonal variation and stratification caused by a substantial freshwater input by deglacial processes. Similarly, the relative abundance of $B$. tepikiense reached up to $30 \%$ in core M23071 during the last glacial-Holocene transition (Baumann \& Matthiessen 1992). Much higher relative 

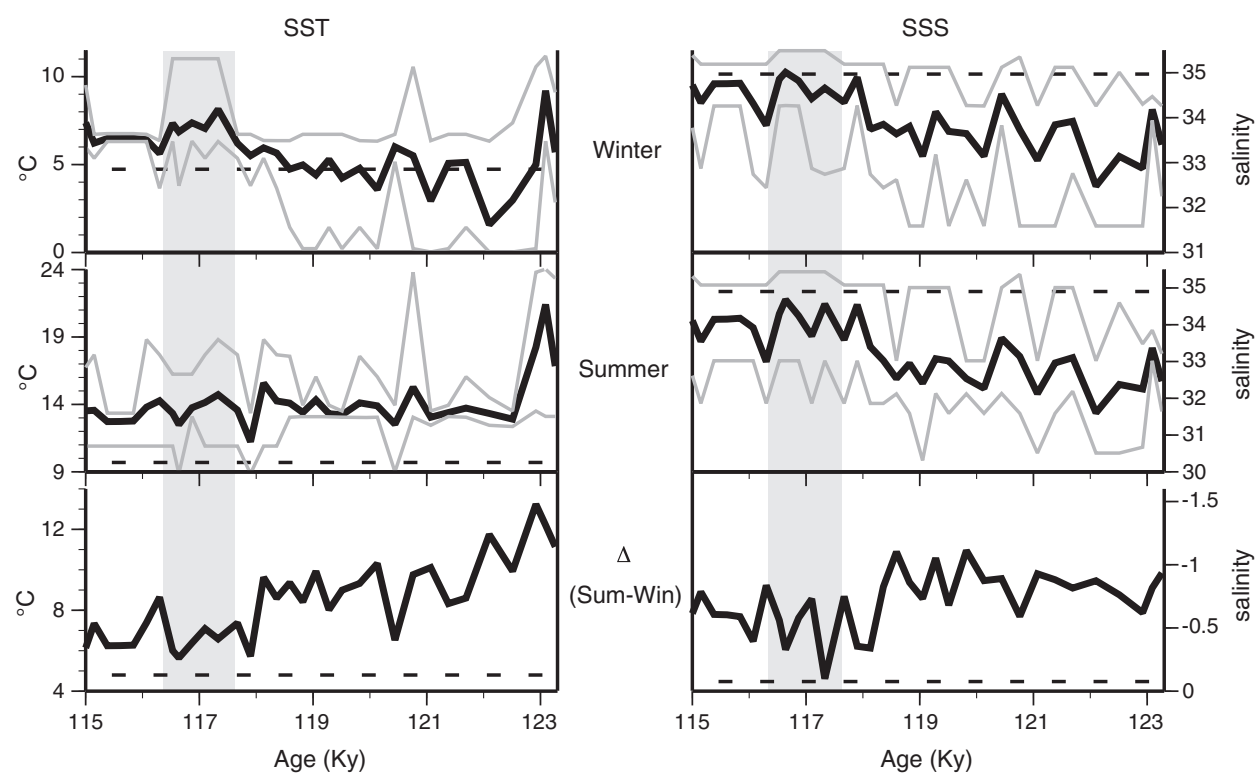

Fig. 5 Sea-surface temperature (SST) and sea-surface salinity (SSS) estimates from the dinoflagellate cyst assemblages for winter and summer, and the difference $(\Delta)$ between both, i.e., the seasonal gradient (lower graph). The dashed horizontal lines indicate the values reconstructed from the core-top sample. The grey bar delineates the time interval with optimal, marine interglacial conditions, as suggested by the peak abundances of Spiniferites mirabilis s.l. and subpolar foraminifera (Van Nieuwenhove et al. 2008).

abundances of the species during MIS 5e with respect to the Holocene were also found south of Iceland (Eynaud et al. 2004), an area also prone to being affected by meltwater input during deglaciation. Ice drifting into our study area would also have replenished the surface layer with nutrients after the spring bloom, allowing phytoplanktic communities to bloom again late in the growing season. Indeed, it has been shown that, in addition to temperature and salinity, the trophic state of the water masses can be an important factor controlling dinoflagellate populations (Dale 1996; Devillers \& de Vernal 2000).

It is intriguing that our planktic oxygen isotope values are on average about $0.3 \%$ lower during MIS 5 e than in the Holocene (Fig. 2). The estimated 4-6-m higher global sea level of MIS 5e (e.g., Chen et al. 1991; McCulloch \& Esat 2000) can only account for a minor part of this isotopic difference. It is therefore often suggested that the climate of the last interglacial period was warmer than the Holocene. For the mid-latitude North Atlantic sector, warmer last interglacial temperatures are confirmed for both the ocean surface and terrestrial realm (e.g, Ruddiman 1986; Guiot et al. 1993; Kandiano et al. 2004). On the other hand, planktic foraminiferal census data from sites further north, in the eastern Norwegian Sea, indicate notably warmer surface waters prevailed in the Holocene (Risebrobakken et al. 2003) compared with the last interglacial (Rasmussen et al. 2003; Van Nieuwenhove et al. 2008). This census data supports a steeper, meridional temperature gradient in the eastern Nordic seas in MIS 5e compared with the Holocene (Bauch et al. 1999).

Salinity also influences the oxygen isotope signal derived from planktic foraminifera, and our lower SSS estimates for most of MIS 5e are an interesting feature in this respect (Fig. 5). It shows that for the interval from ca. 117.5 to $116.5 \mathrm{Kya}$, the $\delta^{18} \mathrm{O}$ values are comparable with the average Holocene value (Figs. 2, 3). The existence of optimal, fully marine interglacial conditions has been interpreted for this time interval, from ca. 117.5 to 1 16.5 Kya, based on time-coeval peak abundances of subpolar foraminifera and the warm dinocyst Spiniferites mirabilis s.l. (Van Nieuwenhove et al. 2008). The SSS estimates and the seasonal gradients in SST and SSS come closest to the reconstructed modern values precisely during this interval of interglacial optimum (Fig. 5). All the records thus seem to point towards the instalment of a surface circulation similar to that of today, bringing relatively warmer Atlantic water and milder winter conditions in the Norwegian Sea for the time between ca. 117.5 and 116.5 Kya. Our data from the dinocyst assemblages thus favour the conclusion that the light oxygen isotopes of the preceding ca. $5.5 \mathrm{Ky}$ of MIS 5e are the result of a differently structured, presumably more stratified, upper water column.

As described above, the timing of the MIS 5e optimum is inferred from peak abundances of subpolar foraminifera and S. mirabilis s.l. (Van Nieuwenhove et al. 2008). The maximum occurrence of $S$. mirabilis s.l. is presently 
found in the Bay of Biscay and off the Iberian margin, where relative abundances of greater than $40 \%$ can be found (Rochon et al. 1999; de Vernal et al. 2005). Several studies have revealed strong affinities of $S$. mirabilis s.l. with the last interglacial period in the temperate latitudes (Eynaud 1999; Sánchez-Goñi et al. 1999; Sánchez-Goñi et al. 2000; Penaud et al. 2008), as well as further north in the South Iceland Basin (Eynaud et al. 2004). These studies and our data all show the presence of $S$. mirabilis s.l. throughout the entire last interglacial period, but with highest relative values during the second half of MIS 5e. This is best seen in samples from south of Iceland, where relative abundances of S. mirabilis s.l. reach over $30 \%$ during the late last interglacial period (Eynaud et al. 2004). Because this site is hydrographically linked to the Vøring Plateau through the flowpath of the NAD, it suggests that $S$. mirabilis s.l. might be a useful indicator for enhanced Atlantic water inflow during the time of interglacial optima in the Nordic seas.

The late MIS 5e marine optimum contrasts with the timing of the Holocene climatic optimum, which occurred during the first half of the Holocene more or less synchronously with relatively high northern summer insolation (e.g., Koç et al. 1993; Bauch et al. 2001; Calvo et al. 2002; Andersen et al. 2004). If the last interglacial climate evolution is taken as an analogue for the Holocene, the present orbital configuration would imply that the time of the Holocene climatic optimum has not yet been reached (Fig. 2; Kukla \& Galvin 2004). However, when comparing the Holocene with MIS 5e, one should consider that both interglacials began quite differently. Although the main deglacial phase had largely ended by 123.5 Kya, it seems as if the continuing presence of IRD, and thus freshwater, during the following $4.5 \mathrm{Ky}$ had a significant impact on the development of MIS 5e. The differing interglacial climate evolution between MIS 5e and the Holocene is also evident in variations observed in the dinocyst assemblage composition over these periods. In spite of the climate variability that occurred during the last $7 \mathrm{Ky}$ (see review by Mayewski et al. 2004), dinocyst assemblages are virtually invariant for this time interval (Baumann \& Matthiessen 1992). On the other hand, the last interglacial dinocyst assemblages show considerable fluctuations among the subordinate species (Fig. 3; see also Van Nieuwenhove et al. 2008). Thus, it appears that short-term surface ocean variability during MIS 5e had a greater impact on the phytoplanktonic communities relative to the late Holocene.

\section{Conclusions}

The comparison of core-top sample and published Holocene dinoflagellate cyst data with samples from the last interglacial period sensu stricto (i.e., with low or no IRD) at site M23071 has revealed the existence of markedly different hydrological conditions in the upper water column of the Norwegian Sea for both interglacial periods. The assemblage compositions, as well as the bestanalogue reconstructions based on them, suggest that a more pronounced seasonality of the surface water and a more strongly stratified upper water layer existed during MIS 5e, further implying surface circulation was different during this time. The difference is expressed in the dinocyst data in two direct ways: first, through B. tepikiense, an abundant species in seasonally stratified water masses, which is presently nearly absent in the Norwegian Sea, but constitutes a sizeable fraction of the last interglacial assemblages; second, with a higher diversity in the last interglacial assemblages, as opposed to the practically bi-specific assemblages of the last $7 \mathrm{Ky}$. Additional evidence for different hydrological surface conditions provided by the dinocyst assemblage data comes from the transfer-function reconstructions. These reconstructions show reduced salinities and greater seasonal differences in SST and SSS for the first ca. $5 \mathrm{Ky}$ of MIS 5e (sensu stricto), as compared with the late Holocene.

The phytoplankton communities appear to have been responding to shorter term surface ocean fluctuations during the last interglacial period: the assemblage variability among dinocysts during MIS 5e contrasts sharply with the stable assemblage composition of the last $7 \mathrm{Ky}$ (Baumann \& Matthiessen 1992). It is conceivable that the evolution during the last interglacial period of the upper water layer is dissimilar to that of the Holocene, in spite of the oft-cited "analogous boundary conditions". The prolonged influence of Termination II, delimited by IRD and thus indicating freshwater input continuing to $119 \mathrm{Kya}$, largely prevented the development of an surface water circulation that is similar to the present type of surface circulation. The marine optimum was reached only after IRD input had ceased completely, i.e., from ca. 117.5 to 116.5 Kya. This late development of the last interglacial optimum is in contrast to the early climatic optimum of the Holocene. The $\delta^{18} \mathrm{O}$ values characterizing the MIS 5e climatic optimum are comparable with the average Holocene values, suggesting that the lighter oxygen isotopes typifying the earlier phases of MIS 5e do not reflect optimal interglacial conditions, but rather reflect the existence of a differently structured ocean surface compared with that of the Holocene.

\section{Acknowledgements}

We are grateful to Jens Matthiessen for providing his raw data and slides from the Holocene section of the core. Taoufik Radi, Anne de Vernal and Maryse Henry 
generously assisted in the processing and interpretation of the transfer-function analysis. The manuscript greatly benefited from the remarks and suggestions made by Kari Grøsfjeld and Vera Pospelova. Brian Haley is thanked for improving the English. This study was funded by the German Research Foundation (project no. BA1367/6).

\section{References}

Andersen C., Koç N., Jennings A. \& Andrews J.T. 2004. Nonuniform response of the major surface currents in the Nordic seas to insolation forcing: implications for the Holocene climate variability. Paleoceanography 19, PA2003, doi: 10.1029/2002PA000873.

Bauch H.A. \& Erlenkeuser H. 2008. A "critical" climatic evaluation of last interglacial (MIS 5e) records from the Norwegian Sea. Polar Research 27, 135-151 (this issue).

Bauch H.A., Erlenkeuser H., Fahl K., Spielhagen R.F., Weinelt M.S., Andruleit H. \& Henrich R. 1999. Evidence for a steeper Eemian than Holocene sea surface temperature gradient between Arctic and sub-Arctic regions. Palaeogeography, Palaeoclimatology, Palaeoecology 145, 95-117.

Bauch H.A., Erlenkeuser H., Grootes P.M. \& Jouzel J. 1996. Implications of stratigraphic and paleoclimatic records of the last interglaciation from the Nordic seas. Quaternary Research 46, 260-269.

Bauch H.A., Erlenkeuser H., Jung S.J.A. \& Thiede J. 2000. Surface and deep water changes in the subpolar North Atlantic during Termination II and the last interglaciation. Paleoceanography 15, 76-84.

Bauch H.A., Erlenkeuser H., Spielhagen R.F., Struck U., Matthiessen J., Thiede J. \& Heinemeier J. 2001. A multiproxy reconstruction of the evolution of deep and surface waters in the subarctic Nordic Seas over the last 30,000 yr. Quaternary Science Reviews 20, 659-678.

Bauch H.A. \& Kandiano E.S. 2007. Evidence for early warming and cooling in North Atlantic surface waters during the last interglacial. Paleoceanography 22, PA1201, doi: 10.1029/2005PA001252.

Baumann K.-H. \& Matthiessen J. 1992. Variations in surface water mass conditions in the Norwegian Sea: evidence from Holocene coccolith and dinoflagellate cyst assemblages. Marine Micropaleontology 20, 129-146.

Beets D.J., Beets C.J. \& Cleveringa P. 2006. Age and climate of the late Saalian and early Eemian type-area, Amsterdam Basin, the Netherlands. Quaternary Science Reviews 25, 876-885.

Berger A.L. 1978. Long-term variations of daily insolation and Quaternary climatic changes. Journal of the Atmospheric Sciences 35, 2362-2367.

Boyer T.P., Antonov J.I., Garcia H.E., Johnson D.R., Locarnini R.A., Mishonov A.V., Pitcher M.T., Baranova O.K. \& Smolyar I.V. 2006. World Ocean Database 2005. In S. Levitus (ed.): NOAA Atlas NESDIS 60. Pp. 1-190. Washington, DC: US Government Printing Office.
Brauer A., Allen J.R.M., Mingram J., Dulski P., Wulf S. \& Huntley B. 2007. Evidence for last interglacial chronology and environmental change from southern Europe. Proceedings of the National Academy of Sciences of the United States of America 104, 450-455.

Calvo E., Grimalt J. \& Jansen E. 2002. High resolution $\mathrm{U}^{\mathrm{k}}{ }_{37}$ sea surface temperature reconstruction in the Norwegian Sea during the Holocene. Quaternary Science Reviews 21, 1385-1394.

Cheddadi R., Mamakowa K., Guiot J., de Beaulieu J.-L., Reille M., Andrieu V., Granoszewski W. \& Peyron O. 1998. Was the climate of the Eemian stable? A quantitative climate reconstruction from seven European pollen records. Palaeogeography, Palaeoclimatology, Palaeoecology 143, 73-85.

Chen J.H., Curran H.A., White B. \& Wasserburg G.J. 1991. Precise chronology of the last interglacial period: 234U-230Th data from fossil coral reefs in the Bahamas. Geological Society of America Bulletin 103, 82-97.

Dale B. 1976. Cyst formation, sedimentation, and preservation: factors affecting dinoflagellate assemblages in recent sediments from Trondheimsfjord, Norway. Review of Palaeobotany and Palynology 22, 39-60.

Dale B. 1996. Chapter 31. Dinoflagellate cyst ecology: modeling and geological applications. In J. Jansonius $\delta$ D.C. McGregor (eds.): Palynology: principles and applications. Pp. 1249-1275. Dallas: American Association of Stratigraphic Palynologists Foundation.

de Vernal A., Eynaud F., Henry M., Hillaire-Marcel C., Londeix L., Mangin S., Matthiessen J., Marret F., Radi T., Rochon A., Solignac S. \& Turon J.-L. 2005. Reconstruction of sea-surface conditions at middle to high latitudes of the Northern Hemisphere during the Last Glacial Maximum (LGM) based on dinoflagellate cyst assemblages. Quaternary Science Reviews 24, 897-924.

de Vernal A., Henry M., Matthiessen J., Mudie P.J., Rochon A., Boessenkool K.P., Eynaud F., Grøsfjeld K., Guiot J., Hamel D., Harland R., Head M.J., Kunz-Pirrung M., Levac E., Loucheur V., Peyron O., Pospelova V., Radi T., Turon J.-L. \& Voronina E. 2001. Dinoflagellate cyst assemblages as tracers of sea-surface conditions in the northern North Atlantic, Arctic and sub-arctic seas: the new " $\mathrm{n}=677$ " data base and its application for quantitative palaeoceanographic reconstruction. Journal of Quaternary Science 16, 681-698.

devillers R. \& De Vernal A. 2000. Distribution of dinoflagellate cysts in surface sediments of the northern North Atlantic in relation to nutrient content and productivity in surface waters. Marine Geology 166, 103-124.

Eriksson B., Grönlund T. \& Uutela A. 1999. Biostratigraphy of Eemian sediments at Mertuanoja, Pohjanmaa (Ostrobothnia), western Finland. Boreas 28, 274-291.

Eynaud F. 1999. Kystes de Dinoflagellés et Evolution paléoclimatique et paléohydrologique de l'Atlantique Nord au cours du Dernier Cycle Climatique du Quaternaire. (Dinoflagellate cysts and palaeoclimatic and palaeohydrologic evolution of the North Atlantic Ocean throughout the last climatic cycle.) PhD thesis, Dept. of Geology and Oceanography, University of Bordeaux 1 . 
Eynaud F., Turon J.-L. \& Duprat J. 2004. Comparison of the Holocene and Eemian palaeoenvironments in the South Icelandic Basin: dinoflagellate cysts as proxies for the North Atlantic surface circulation. Review of Palaeobotany and Palynology 128, 55-79.

Eynaud F., Turon J.L., Sánchez-Goñi M.F. \& Gendreau S. 2000. Dinoflagellate cyst evidence of "Heinrich-like events" off Portugal during the marine isotopic stage 5. Marine Micropaleontology 40, 9-21.

Fronval T. \& Jansen E. 1997. Eemian and early Weichselian (140-60 ka) paleoceanography and paleoclimate in the Nordic Seas with comparison to Holocene conditions. Palaeoceanography 12, 443-462.

Gerlach S.A., Thiede J., Graf G. \& Werner F. 1986. Forschungsschif Meteor, Reise 2 vom 19. Juni bis 16, Juli 1986, Forschungsschif Poseidon, Reise 128 vom 7. Mai bis 8. Juni 1986. (RV Meteor, Expedition 2, 19 June to 16 July 1986, RV Poseidon, Expedition 128, 7 May to 8 June 1986.) Berichte aus dem Sonderforschungsbereich 313, vol. 4. Kiel: University of Kiel.

Grøsfjeld K., Funder S., Seidenkrantz M.-S. \& Glaister C. 2006. Last interglacial marine environments in the White Sea region, northwestern Russia. Boreas 35, 493-520.

Grøsfjeld K., Larsen E., Sejrup H.P., de Vernal A., Flatebø T., Vestbø M., Haflidason H. \& Aarseth I. 1999. Dinoflagellate cysts reflecting surface-water conditions in Voldafjorden, western Norway during the last 11300 years. Boreas 28, 403-415.

Guiot J. 1990. Methodology of the last climatic cycle reconstruction in France from pollen data. Palaeogeography, Palaeoclimatology, Palaeoecology 80, 49-69.

Guiot J., de Beaulieu J.L., Chedaddi R., David F., Ponel P. \& Reille M. 1993. The climate in western Europe during the last glacial/interglacial cycle derived from pollen and insect remains. Palaeogeography, Palaeoclimatology, Palaeoecology 103, 73-93.

Haake F.W., Erlenkeuser H. \& Pflaumann U. 1992: Pullenia bulloides (ORBIGNY) in sediments of the Norwegian/ Greenland Sea and the northeastern Atlantic Ocean: paleo-oceanographic evidence. In Y. Takayanagi \& T. Saito (eds.): Studies in benthic foraminifera, Benthos '90. Pp. 235-244. Sendai, Japan: Tokai University Press.

Harland R. 1983. Distribution maps of recent dinoflagellate cysts in bottom sediments from the North Atlantic Ocean and adjacent seas. Palaeontology 26, 321-387.

Head M.J. 2007. Last interglacial (Eemian) hydrographic conditions in the southwestern Baltic Sea based on dinoflagellate cysts from Ristinge Klint, Denmark. Geological Magazine 144, 987-1013.

Head M.J., Seidenkrantz M.-S., Janczyk-Kopikowa Z., Marks L. \& Gibbard P.L. 2005. Last Interglacial (Eemian) hydrographic conditions in the southeastern Baltic Sea, NE Europe, based on dinoflagellate cysts. Quaternary International 130, 3-30.

Hopkins T.S. 1991. The GIN Sea-a synthesis of its physical oceanography and literature review 1972-1985.

Earth-Science Reviews 30, 175-318.
Kandiano E.S., Bauch H.A. \& Müller A. 2004. Sea surface temperature variability in the North Atlantic during the last two glacial-interglacial cycles: comparison of faunal, oxygen isotopic, and $\mathrm{Mg} / \mathrm{Ca}$-derived records.

Palaeogeography, Palaeoclimatology, Palaeoecology 204, 145-164.

Koç N., Jansen E. \& Haflidason H. 1993. Paleoceanographic reconstructions of surface ocean conditions in the Greenland, Iceland and Norwegian seas through the last 14 ka based on diatoms. Quaternary Science Reviews 12, 115-140.

Kukla G. \& Galvin J. 2004. Milankovitch climate reinforcements. Global and Planetary Change 40, 27-48.

Laskar J., Robutel P., Joutel F., Gastineau M., Correia A.C.M. \& Levrard B. 2004. A long-term numerical solution for the insolation quantities of the Earth. Astronomy and Astrophysics 428, 261-285.

Mangerud J. 1989. Correlation of the Eemian and the Weichselian with deep sea oxygen isotope stratigraphy. Quaternary International 3, 1-4.

Mangerud J., Sønstegaard E. \& Sejrup H.-P. 1979. Correlation of the Eemian (interglacial) stage and the deep-sea oxygen-isotope stratigraphy. Nature 277, 189-192.

Marret F., Eiriksson J., Knudsen K.L., Turon J.-L. \& Scourse J.D. 2004. Distribution of dinoflagellate cyst assemblages in surface sediments from the northern and western shelf of Iceland. Review of Palaeobotany and Palynology 128, 35-53.

Marret F. \& Zonneveld K. 2003. Atlas of modern organic-walled dinoflagellate cyst distribution. Review of Palaeobotany and Palynology 125, 1-200.

Martinson D.G., Pisias N.G., Hays J.D., Imbrie J., Moore Jr. T.C. \& Shackleton N. 1987. Age dating and the orbital theory of the ice ages: development of a high-resolution 0 to 300,000-year chronostratigraphy. Quaternary Research 27, $1-29$.

Matthiessen J. 1995. Distribution patterns of dinoflagellate cysts and other organic-walled microfossils in recent Norwegian-Greenland Sea sediments. Marine Micropaleontology 24, 307-334.

Matthiessen J., de Vernal A., Head M., Okolodkov Y., Zonneveld K. \& Harland R. 2005. Modern organic-walled dinoflagellate cysts in Arctic marine environments and their (paleo-) environmental significance. Paläontologische Zeitschrift 79, 3-51.

Matthiessen J. \& Knies J. 2001. Dinoflagellate cyst evidence for warm interglacial conditions at the northern Barents Sea margin during marine oxygen isotope stage 5. Journal of Quaternary Science 16, 727-737.

Matthiessen J., Knies J., Nowaczyk N.R. \& Stein R. 2001. Late Quaternary dinoflagellate cyst stratigraphy at the Eurasian continental margin, Arctic Ocean: indications for Atlantic water inflow in the past 150000 years. Global and Planetary Change 31, 65-86.

Mayewski P.A., Rohling E.E., Stager J.C., Karlén W., Maasch K.A., Meeker L.D., Meyerson E.A., Gasse F., van Kreveld S., Holmgren K., Lee-Thorp J., Rosqvist G., Rack F., 
Staubwasser M., Schneider R.R. \& Steig E.J. 2004. Holocene climate variability. Quaternary Research 62, 243-255.

McCulloch M.T. \& Esat T. 2000. The coral record of last interglacial sea levels and sea surface temperatures. Chemical Geology 169, 107-129.

Overpeck J., Webb T. \& Prentice I.C. 1985. Quantitative interpretation of fossil pollen spectra: dissimilarity coefficients and the method of modern analogs. Quaternary Research 23, 87-108.

Paillard D., Labeyrie L. \& Yiou P. 1996. Macintosh program performs time-series analysis. EOS, Transactions of the American Geophysical Union 77, 379.

Penaud A., Eynaud F., Turon J.L., Zaragosi S., Marret F. \& Bourillet J.F. 2008. Interglacial variability (MIS 5 and MIS 7) and dinoflagellate cyst assemblages in the Bay of Biscay (North Atlantic). Marine Micropaleontology, doi: 10.1016/ j.marmicro.2008.01.007.

Radi T. \& de Vernal A. 2008. Dinocysts as proxy of primary productivity in mid-high latitudes of the Northern Hemisphere. Marine Micropaleontology, doi: 10.1016/ j.marmicro.2008.01.012.

Rasmussen T.L., Thomsen E., Kuijpers A. \& Wastegård S. 2003. Late warming and early cooling of the sea surface in the Nordic seas during MIS 5e (Eemian Interglacial). Quaternary Science Reviews 22, 809-821.

R Development Core Team 2007. R: A language and environment for statistical computing. Vienna: R Foundation for Statistical Computing. Available on the internet at http://www.R-project.org.

Rioual P., Andrieu-Ponel V., Rietti-Shati M., Battarbee R.W., de Beaulieu J.-L., Cheddadi R., Maurice R., Svobodova H. \& Shemesh A. 2001. High-resolution record of climate stability in France during the last interglacial period. Nature 413, 293-296.

Risebrobakken B., Jansen E., Andersson C., Mjelde E. \& Hevrøy K. 2003. A high-resolution study of Holocene paleoclimatic and paleoceanographic changes in the Nordic seas. Paleoceanography 18, 1017, doi: 10.1029/ 2002PA000764.

Rochon A., de Vernal A., Sejrup H.-P. \& Haflidason H. 1998. Palynological evidence of climatic and oceanographic changes in the North Sea during the last deglaciation. Quaternary Research 49, 197-207.

Rochon A., de Vernal A., Turon J.-L., Matthiessen J. \& Head M. 1999. Distribution of recent dinoflagellate cysts in surface sediments from the North Atlantic Ocean and adjacent seas in relation to sea-surface parameters. Dallas: American Association of Stratigraphic Palynologists Foundation.

Rohling E.J., Grant K., Hemleben C., Siddall M., Hoogakker B.A.A., Bolshaw M. \& Kucera M. 2008. High rates of sea-level rise during the last interglacial period. Nature Geoscience 1, doi: 10.1038/ngeo.2007.28.

Rousseau D.D., Hatté Ch., Guiot J., Duzer D., Schevin P. \& Kukla G. 2006. Reconstruction of the Grande Pile Eemian using inverse modelling of biomes and $\mathrm{d}^{13} \mathrm{C}$. Quaternary Science Reviews 25, 2806-2819.
Ruddiman W.F., Shackleton N.J. \& McIntyre A. 1986: North Atlantic sea-surface temperatures for the last 1.1 million years. In C.P. Summerhayes \& N.J. Shackleton (eds.): North Atlantic paleoceanography. Pp. 155-173. London: Geological Society.

Sánchez-Goñi M.F., Eynaud F., Turon J.-L. \& Shackleton N.J. 1999. High resolution palynological record off the Iberian margin: direct land-sea correlation for the last interglacial complex. Earth and Planetary Science Letters 171, 123-137.

Sánchez-Goñi M.F., Turon J.-L., Eynaud F., Shackleton N.J. \& Cayre O. 2000. Direct land/sea correlation of the Eemian, and its comparison with the Holocene: a high-resolution palynological record off the Iberian margin. Netherlands Journal of Geosciences 79, 345-354.

Shackleton N.J. 1969. The last interglacial in the marine and terrestrial records. Proceedings of the Royal Society B174, 135-154.

Shackleton N.J., Sánchez-Goñi M.F., Pailler D. \& Lancelot Y. 2003. Marine isotope substage 5 e and the Eemian Interglacial. Global and Planetary Change 36, 151-155.

Stockmarr J. 1971. Tablets with spores used in absolute pollen analysis. Pollen Spores 13, 616-621.

Svendsen J.I., Alexanderson H., Astakhov V.I., Demidov I., Dowdeswell J.A., Funder S., Gataullin V., Henriksen M., Hjort C., Houmark-Nielsen M., Hubberten H.W., Ingólfsson Ó., Jakobsson M., Kjær K.H., Larsen E., Kokrantz H., Pekka Lunkka J., Lyså A., Mangerud J., Matiouchkov A., Murray A., Möller P., Niessen F., Nikolskaya O., Polyak L., Saarnisto M., Siegert C., Siegert M.J., Spielhagen R.F. \& Stein R. 2004. Late Quaternary ice sheet history of northern Eurasia. Quaternary Science Reviews 23, 1229-1271.

Van Leeuwen R.J.W., Beets D.J., Bosch J.H.A., Burger A.W., Cleveringa P., Van Harten D., Herngreen G.F.W., Kruk R.W., Langereis C.G., Meijer T., Pouwer R. \& de Wolf H. 2000. Stratigraphy and integrated facies analysis of the Saalian and Eemian sediments in the Amsterdam-Terminal borehole, the Netherlands. Netherlands Journal of Geosciences 79, 161-196.

Van Nieuwenhove N., Bauch H.A. \& Matthiessen J. 2008. Last interglacial surface water conditions in the eastern Nordic seas inferred from dinocyst and foraminiferal assemblages. Marine Micropaleontology 66, 247-263.

Vogelsang E. 1990. Paläo-Ozeanographie des Europäischen Nordmeeres anhand stabiler Kohlenstoff- und Sauerstoffisotope. (Paleoceanography of the Nordic seas based on stable carbon and oxygen isotopes.) Berichte aus dem Sonderforschungsbereich 313, vol. 23. Kiel: University of Kiel.

Voelker A.H.L. 1999. Zur Deutung der Dansgaard-Oeschger Ereignisse in ultra-hochauflösenden Sedimentprofilen aus dem Europäischen Nordmeer. (Dansgaard-Oeschger events in ultra-high resolution sediment records from the Nordic seas.) Report Institut für Geowissenschaften, Kiel University, 9.

Zonneveld K.A.F., Versteegh G.J.M. \& de Lange G.J. 2001. Palaeoproductivity and post-depositional aerobic organic matter decay reflected by dinoflagellate cyst assemblages of the Eastern Mediterranean S1 sapropel. Marine Geology 172, $181-195$. 